\title{
The Sociology of Disability and the Struggle for Inclusive Education
}

\section{Introduction}

The development of the field of sociology of disability can be attributed to a small number of key scholars (Len Barton, Sally Tomlinson and Mike Oliver) and is characterised by a significant shift in the analysis of the nature and causes of disability from individualistic to social and material frames of reference. This field, however, has been a somewhat troubled and contested one, with intensive battles over identity and presence and a series of active erasures and absences - the removal of the body from the social model of disability; the disappearance of the Other from educational policies and practices; disability academics' own absence from political discourse and action. These battles, and the ensuing erasures, have done little to advance the struggle for inclusive education and more voices than ever before can be heard to challenge the very idea. This article charts the emergence of the sociology of disability and examines the areas of contestation. It considers the contribution of the sociology of disability to inclusive education and examines some of the objections to it currently being voiced. The paper ends with some reflections on the possibilities for alternative forms of engagement by academics within the sociology of disability and outlines a series of duties that may make inclusive education more feasible and more capable of making a material difference to the lives of disabled children.

\section{The sociology of disability}

The sociology of disability emerged in the 1980s as a direct challenge to the weighty paradigm of special education, with its fixation on individual deficits and remedies. Len Barton's (1988) The politics of special educational needs; Sally Tomlinson's 
(1981) Educational subnormality: A study in decision-making and (1982) A sociology

of special education; Len Barton and Sally Tomlinson's jointly authored Special education and social interests (1984); and Julienne Mongon, Denis Ford and Maurice Whelan's (1982) Special education and social control: Invisible disasters abruptly turned the gaze away from the child and highlighted the role of institutional structures and practices in producing school failure. Disabled academics Mike Oliver (1996), Colin Barnes (Barnes and Mercer 2002), Sally French (1993; 1994; Swain and French 2008), Tom Shakespeare (1999; 2006; Barnes, Mercer and Shakespeare 1999), Jenny Morris (1991) and Carol Thomas (2007) have also provided significant sociological analyses which have identified disability as being produced by environmental, structural and attitudinal barriers.

Barton (2001) has subsequently outlined the clear function and duty of the sociology of disability:

A political analysis which is inspired by a desire for transformative change and that constitutes hope at the centre of the stuggles ... At both an individual and collective level a crucial task is to develop a theory of political action which also involves the generation of tactics or strategies for its implementation. This is a difficult but essential agenda (3).

This agenda has been difficult for sociology in general as well as for the sociology of disability and there has been much agonising about the challenge of insulating research from value bias whilst contributing to social change through research (Gewirtz and Cribb 2006). Hammersley (2008) has argued forcefully that politically 
committed research is incompatible with academic rigour, but Gewirtz and Cribb (2008) and others (Flvyberg 2001; Walford et al 1994) have insisted that a sociology bound by ethical reflexivity can be both more responsible and methodologically rigorous. For the sociology of disability, there seems to have been no problem in accepting the political commitment but some difficulties in enacting it.

\section{Erasures in the field}

The sociology of disability, as a field, has struggled to maintain both a presence and an authority. It is possible to discern three significant erasures within the field of sociology of disability which have had negative consequences for it. The first of these concerns the efforts to remove the disabled body from the social model of disability. The second is the more widespread disappearance of the Other, disabled or different in some other way, within educational policies and practices and the third is the absence of academics (partly by their own hand) from political discourse and action.

\section{Missing persons in the social model of disability}

Mike Oliver has expressed his disappointment that the social model of disability, developed by disabled people, has not been used as a tool for altering the material circumstances of disabled people and fostering inclusion and wishes that people would use the social model, rather than continue to debate it:

I wish people would stop talking about it. The social model is not some kind of conceptual device to debate. The social model is a tool that we should use to try and produce changes in the world, changes in what we do. What I hoped from that was that people would start using it and what we would actually see was not 
'what are the theoretical underpinnings of the social model?' ... but 'this is what I actually did with the social model. This is how I took it into a particular school or a particular social work agency. This is what we did with it and this whether it worked or not' (Allan and Slee 2008, 88).

The social model was developed to counter the formidable tragedy discourse that surrounds disabled people and which depicts disability as a deficit, a tragedy and 'abnormal, and something to be avoided at all costs' (Oliver and Barnes 1996, 66; original emphasis). However, as Swain and French (2008) point out, the tragedy model of disability plays on people's fears of their own mortality and vulnerability and is ingrained in society, with the effect of silencing and excluding disabled people.

Shakespeare (2006) contends that there are significant problems with the social model and it has become an obstacle to the development of the disability movement and to disability studies:

I have come to the conclusion that the British social model of disability studies has reached a dead end, having taken a wrong turn back in the 1970s when the Union of Physically Impaired Against Segregation (UPIAS) social model conception became the dominant UK understanding of disability ... At one time I was a critical friend of the social model, defending it against external attack (Shakespeare and Watson 1997): I am now among those who argue that it should be abandoned (3-5). 
The inability to come up with an adequate theory of disability is, according to Paterson and Hughes (2000), 'one of the more spectacular failures of modern sociological research' (42). Shakespeare suggests that the problems of the social model are, paradoxically, also its successes. It was developed as a political intervention rather than a social theory; it was strongly tied into identity politics; and it was defended as correct by its initial proponents, but not subjected to revision over the thirty years of its life. Separating impairment from disability was an important move to privilege the material causes of disability and to force the removal of these, but it has led to a disavowal of impairment - because 'frailty offends' (Hughes 2009, 401) - which many disabled people have found difficult to accept:

As individuals, most of us simply cannot pretend with any conviction that our impairments are irrelevant because they influence every aspect of our lives. We must find a way to integrate them into our whole experience and to identify for the sake of our physical and emotional well-being and, subsequently, for our capacity to work against Disability (Crow 1992, 7).

French (1993) is sympathetic to the need to present disability in a 'straightforward, uncomplicated manner in order to convince a very sceptical world' (24) that it is society, rather than individuals, that has to be changed. Nevertheless, the dogmatic defence of the social model as orthodoxy is, according to Shakespeare (2006), problematic and has contributed to the exclusion of the disability movement: 
Alone amongst radical movements, the UK disability rights tradition has, like a fundamentalist religion, retained its allegiance to a narrow reading of its founding assumptions (Shakespeare 2006, 34).

Shakespeare and other commentators (Paterson and Hughes 1999) have contended that the social model needs to become more sophisticated if it is to be relevant to the lives of disabled people or at least used more reflexively (Corker 1999). This heightened sophistication can be seen in two separate refinements of the social model. The first is the development of an 'affirmation model', led by John Swain and Sally French (2008), which rejects tragic depictions of disabled people and associated notions of dependency and abnormality and affirms and validates the experiences of disabled people. It also acknowledges the significance of individuals' impairments, something that was not possible within the social model. The second refinement entails enabling disabled people to reclaim their disabled bodies from the purely social construction of disability (Shakespeare 1996; Hughes 2009) and procuring vulnerability and frailty as 'an inalienable condition of becoming' (Shildrick 2002, 85). This, argues Hughes (2009), allows the binaries of disability/impairment and the disabled/normal body to be dismantled or at least undermined. Both of these developments of the social model have the potential to re-politicise disability and to provide a new subjectification of the disabled person who is simultaneously impaired and oppressed (Shakespeare 2006).

\section{The disappeared Other in education}

Education is characterised by what Derrida (1992) calls aporias, which are oppositional or contradictory imperatives. Such oppositions, for example between 
raising achievement and promoting inclusion, or between educating individuals to be able hold their own in the competitive world, and ensuring those individuals can collaborate, co-operate and understand their civic responsibilities, are constructed in educational policies and practices as choices to be made and are often resolved by privileging one imperative over another, in a way that the obligation to the 'Other' the disabled person or the individual with learning difficulties - is denied. This forgetfulness of the Other becomes formalised and justified through policies and practices which endorse solution, resolution and 'the desire for translation, agreement and univocity' (Derrida 1992, 78). The decisiveness called for within education forces closure and is, according to Derrida (1992), irresponsible and a 'madness' (26), because the way forward is clear, undecidability is denied and possibilities are removed. All that remains is a technical solution: 'one simply applies or implements a program' (Derrida 1992, 41). It produces injustice:

Injustice - not to mention racism, nationalism and imperialism - begins when one loses sight of the transcendence of the Other and forgets that the State, with its institutions, is informed by the proximity of my relation to the Other (Critchley 1999, 233).

In education, frameworks of accountability and performativity are defended by governments on the basis of inclusion, entitlement and equity, when evidence points to the injustices produced by such frameworks for both professionals and those for whom they are responsible (Allan 2008; Booth 2003; Smyth 2000; Torrance 2008). In the UK, injustices in relation to disability, ethnicity, class and gender are abundantly clear (Gillbourn and Youdell 2000; Gamarnikow and Green 2009). Paradoxically the 
removal of the Other comes through a pathologising and naming of individuals in relation (only) to their deficits. Thomas (2008) calls this a 'closure on learning' (7) which produces and reinforces disabled, ethnic, class and gendered identities as both failures and in their 'sameness' (Garrison 2008, 273) to others.

\section{Absent colleagues}

Barton and Clough (1995) underlined the obligations and responsibilities of those working in the field of disability, especially within academic positions, and posed these as questions:

- What responsibilities arise from the privileges I have as a result of my social position?

- How can I use my knowledge and skills to challenge, for example, the forms of oppression disabled people experience?

- Does my writing and speaking reproduce a system of domination or challenge that system? (144).

Academics have, however, been slow to take up these responsibilities and, as Davis (2002) notes, political and academic movement around disability 'has been 'at best, a first or second wave enterprise' (10). Skrtic (1995) sees the problem as lying with inclusive education researchers simply following the same patterns as the integration debate and engaging in 'naïve pragmatism' (80), merely criticising special education practices and not engaging in systematic analysis of their underlying assumptions. Erevelles (2006) recalls how, as a doctoral student, her efforts to initiate political discussions about the interconnections between race and disability were met with 
'polite disinterest' (363) by her teachers and led to 'non-conversations' (ibid). Oliver (1999) has been more vociferous in his criticism of academics' failure to use their positions and power to alter the material conditions of disabled people. He has described them as 'parasitic upon disabled people' (184) and has accused those undertaking research of having appropriated the experiences of disabled people and, in so doing, of 'shitting disabled people' (187; original emphasis). The enjoinder to non-disabled academics is not to withdraw from disability research but to 'put disabled people at the centre of the picture' (Shakespeare, 2006, 186) and to be accountable to organisations of disabled people.

Several academics have argued that the 'audit culture' (Strathern 1997; 2000) within higher education has undermined academic culture and autonomy (Paterson 2003) and limited their capacity to influence communities and their values. Evans (2004) contends that the regulatory practices within universities is 'producing fear and little else' (Evans 2004, 63) and is 'killing thinking' (ibid), while Furedi (2004) wonders 'where have all the intellectuals gone?' (vii) if they were ever there in the first place. A further danger for the intellectual, according to Said (1994), comes from the limitations and constraints of professionalism that encourage conformity rather than critique:

The particular threat to the intellectual today, whether in the West or the non-Western world, is not the academy, nor the suburbs, not the appalling commercialism of journalism and publishing houses, but rather an attitude that I will call professionalism. By professionalism I mean thinking of your work as an intellectual as something you do for a living, between the 
hours of nine and five with one eye on the clock, and another cocked at what is considered to be proper, professional behaviour - not rocking the boat, not straying outside the accepted paradigms or limits, making yourself marketable and above all presentable, hence uncontroversial and unpolitical and 'objective' (55; original emphasis).

Derrida reminds us that to profess, either as members of a professional group or as academics, is to make a performative declaration of faith and commitment which exceeds techno-scientific knowledge (Cohen 2001) even though it may be reducible to this. Said's point that the commitment to professionalism, and the accountability that goes with it, can produce a kind of quietism is well made. I would suggest however, that frameworks of accountability, far from overwhelming and constraining academics, enables them to evade responsibility for the Other.

\section{Struggling to include?}

The sociology of disability has successfully directed attention to the structural and material causes of disability and failure and has oriented analyses of inclusive education towards the identification of exclusionary pressures. The simultaneous analysis of exclusion and inclusion has been recognised by many scholars as vital if inclusive education is to be properly understood and enacted (Ballard 2003; Booth and Ainscow 1998). Yet, in spite of this awareness, we appear to be no closer to an understanding of how to achieve inclusive education. Dyson and his team (2002), who undertook a systematic review of research on inclusion, found that few 'golden solutions' had been produced. At the same time, there is no shortage of technical help in the form of easy guides to inclusive education. These texts present as 'authoritative 
purveyors of technical knowledge' (Brantlinger 2006, 67) and portray idealised versions of classroom life and of children benefiting from interventions. They offer simple, easy to implement, strategies for managing difference such as ' 60 researchbased teaching strategies that help special learners succeed' (McNary, 2005) or 'commonsense methods for children with special educational needs' (Westwood, 2002) and fail to explore issues of inclusion, equity and justice in anything other than a superficial way. When beginning teachers encounter difference in their classrooms it bears no resemblance to the textbook portrayals. Although the problematic nature of these appears to be uniform, Brantlinger (2006) takes particular exception to the US hardbacks - 'the big glossies' (45). Furthermore, the textbooks affect a sound theoretical base, but as Thomas (2008) observes, they amount to little more than 'theory junk sculpture' (1), a 'cacophany of incompatible explanations,' (ibid) in which 'plausible homily, mixed with large portions of psychoanalytic and psychological vocabulary, take the place of a rational consideration of children's behaviour at school' (ibid). A rational consideration might involve putting the social model to use, as Oliver (1996) recommended, and seeking to remove barriers to participation, but this is not forthcoming from the textbooks which are instead intent on highlighting, and then generalising about, children's deficits. The textbooks command an authority which is reassuring, especially to new teachers, but their intent to persuade new teachers that difference is easy makes them deeply irresponsible.

Barton (1997) specified clearly that inclusive education involved the twofold activity of increasing participation and removing exclusionary barriers. Suspicions have been voiced, however, that inclusive education has merely been a new name under which exclusionary special education practices have been replicated (Slee 1993; 2001; Slee 
and Allan 2001). Slee (2003) has drawn attention to the oxymoronic nature of the term inclusive education itself, pointing out that schools were never meant to be for everyone and must, in order to function, position some individuals as failures, and indeed inclusion within classrooms may be an impossibility as long as the more widespread and systemic exclusion within the education system remains.

Researchers have reported serious resistance to inclusion by teachers (Croll and Moses 2000; Thomas and Vaughan 2004) and a lack of confidence in their capacity to deliver inclusion with existing resources (Mittler 2000; Hanko 2005). Macbeath et al (2006) found teachers were positive about inclusion but did not see it as appropriate for children with complex emotional needs. Tom Shakespeare (2005) has suggested that there is a measure of 'hysteria,' 'moral panic' and an 'alarming backlash against the principle of inclusion', while Dyson (2001) contends that tensions within the inclusion movement have led to a 'recalibration' (27) of inclusion which amounts to pleas for 'old fashioned integration' (ibid).

Even the 'architect' of inclusion, Mary Warnock, has subsequently claimed to regard the idea of inclusion to have been 'disastrous' $(2005,22)$. In a pamphlet published by the Philosophy of Education Society of Great Britain, she declared it to have been a mistake to have thought that all children could succeed in mainstream schools and lamented that 'children are the casualities' (ibid, 14) of this mistake. Her call for a return to segregated schooling, at least for some people, was denounced roundly by inclusion commentators such as Barton (2005) and Norwich (2006), who expressed disappointment and puzzlement at her lack of familiarity with the field of inclusion and its current debates, but was seen as a vindication by others (Spurgeon 2006; Wing 
2006) and as an indication that 'the tide is turning on SEN provision' (Gloucestershire Special Schools Protection League 2005). Although Barton (2005) elegantly dismissed Warnock's pronouncements as ignorant and offensive, he also expressed some concern about her 'naïve and politically reactionary demand' (4) for acceptance that 'even if inclusion is an ideal for society in general, it may not always be an ideal for school' (Warnock 2005, 43). He warned that such thinking, if realised in practice, 'will contribute to the building up of serious individual and socially divisive problems for the future' (Barton 2005, 4).

\section{New forms of engagement}

Try again. Fail Again. Fail better (Beckett, 1992, Westward Ho, 101)

The troubles within the field of the sociology of disability have, I have argued, limited its capacity as a transformative and political social theory and restricted the acquisition of knowledge about the means of accomplishing inclusive education. Whilst this is, in some respects, disappointing, it is the very disappointment that comes from the recognition of injustice that could provoke the need for a response from the sociology of disability that is ethical and that rescues disabled people, and the Other more generally, from obscurity and denial. Thus the failures caused by a lack of responsibility could be redressed by the establishment of an ethics which 'might be able to face and face down the iniquities of the present' (Critchley 2007, 88). Such an ethics, informed by Levinas $(1969 ; 1999)$ and constituting a reorientation to human subjectivity, has as its core an absolute responsibility to the Other and an asymmetrical relation to the Other because of ones' own inadequacy in the face of the 
demand of the Other (Critchley 2007). This relationship is both aporetic, in the sense of having double contradictory imperatives, and infinite:

The idea of the infinite consists precisely and paradoxically in thinking more than what is thought while nevertheless conserving it in its excessive relation to thought. The idea of the infinite consists in grasping the ungraspable while nevertheless guaranteeing its status as ungraspable (Levinas 1969, 19).

The relationship is also experienced, because of an inadequacy in the face of the Other, as not benign, but as a responsibility that 'persecutes me with its sheer weight' (Critchley 2007, 59) and produces an absolute imperative towards the Other which is a 'gratuitous and non-transferable responsibility, as if they were chosen and unique and in which the other were absolutely other, i.e ... still incomparable and thus unique' (Levinas 1999, 170). This responsibility is inescapable:

to be a "self" is to be responsible before having done anything ... I am not merely the origin of myself, but I am disturbed by the Other. Not judged by the Other, but condemmed without being able to speak, persecuted' (Levinas 1996, 94).

It is also a vital part of what it is to be human: 'Let's face it. We're undone by each other. And if not, we're missing something' (Butler 2004, 43). 
Academic 'duties'

Bourdieu (1998) maintains that it is vital that academics are protected from urgent duties and that they can be allowed to 'play seriously' (128):

Homo scholasticus or homo academicus is someone who can play seriously because his or her state (or State) assures her the means to do so, that is, free time, outside the urgency of a practical situation' (ibid).

An ethics could enable academics to have greater control and to engage in serious play. The foregrounding of the responsibility to the Other makes the academic's role explicitly a political one and although finding "the gap between "is" and "ought" that politics hides out (Gates 1992, 330) may be difficult, it could be achieved by undertaking a number of specific duties.

The first duty for the academic involves the articulation of new political subjectivities, by privileging the voices of minorities and marginalised groups and mobilizing politically around these.. This is done by naming these groups, since, as Critchley reminds us, politics always requires naming a political subjectivity and organising around it. Ranciere (2008) usefully describes this process of naming making a discourse of that which has formerly been a noise and a process of rupture that renders certain identities visible:

For me a political subject is a subject who employs the competence of the socalled incompetents or the part of those who have no part, and not an additional 
group to be recognised as part of society ... It's a rupture that opens out into the recognition of the competence of anyone, not the addition of a unit (3).

Critchley (2007) cites examples of 'indigenous' becoming a political force and achieving change in Mexico and Australia as a result of the process of claiming this name. In Mexico, recognising that the name 'peasant' no longer had any purchase, activists sought to enforce acceptance of a collective indigenous identity and Australian Aboriginals forcefully cemented the challenge to land rights through the establishment of a beach umbrella on the lawn facing the National Parliament which it named the 'Aboriginal Tent Embassy' (108). Critchley advocates a kind of demonstration as demos-tration on behalf of minorities, 'manifesting the presence of those who do not count,' (130) and this could be undertaken in research, writing and teaching. The dangers of patronage, of denying individuals their singular identity or of spectacularising their difference are, however, strong and should be guarded against.

A second duty involves finding a new language of civil disobedience which does not place one's own position at risk, but which nevertheless interrupts serious exchanges through the (re)introduction of the Other. This may be done through a kind of 'tactical frivolity' (Critchley 2007, 12), an example of which, on a large scale, could be seen in 'Ya Basta', in which groups dress in ridiculous, misshapen outfits, as fairies or in camp evening wear and tease riot police (by tickling them or giving them fake money to thank them for repressing dissent) or through more dialogic means. Plato takes up Socrates' notion of a particularly annoying, but persistent, gadfly: 
... if I may use such a ludicrous figure of speech, [I] am a sort of gadfly, given to the state by God; and the state is a great and noble steed who is tardy in his motions owing to his very size, and requires to be stirred into life. I am that gadfly which God has attached to the state, and all day long and in all places am always fastening upon you, arousing and persuading and reproaching you. You will not easily find another like me, and therefore I would advise you to spare me. (Plato, cited in Kraut 1992)

Whilst the image of the gadfly is seductive, I am not proposing that the academic engages in a Socratic dialogue because this is a process that is too constraining and closed. Rather, the gadfly's effect is to open up to the Other and to be ready to respond to what is forthcoming.

A third duty follows a recommendation by Torrance (2008) and is concerned with making alliances with sponsors of research and policymakers and designing research in collaboration with, rather than on behalf of, them. It is here that the academic can introduce uncertainty into the sphere of inclusive education and research upon it and, through dialogue, can design and undertake research that is genuinely investigative. Biesta's (2008) notion of 'pedagogy with empty hands' (198), although depicting an approach to educating, is an extremely useful way of thinking about the research relationship. It requires approaching the others in the relationship without ready solutions or 'tricks of the trade' (208), derived from research or elsewhere, and asking 'what do you think of it?' (ibid) In such a relationship it will be possible to talk through 'the issues of validity, warrant, appropriateness of focus and trustworthiness of results,' as Torrance $(2008,522)$ advocates. Academics may also be able to open 
sponsors' and policymakers' eyes to the aporetic features of the educational terrain and, following Samuel Beckett, could offer, as an alternative to success criteria, frameworks for failing effectively. Such an approach has been attempted in a recent knowledge exchange activity within a programme, Sistema Scotland, which was attempting social inclusion through music. Presenting the policy choices to the programme managers as aporias proved difficult and uncomfortable for them but it forced them to consider how their decisions could create the exclusion of particular groups (Allan et al, 2010). The sociology of disability could potentially make a significant contribution through concepts, language, and in relation to thinking itself. Torrance advocates that we 'acknowledge the imperfections of what we do' (2008, 523), but these imperfections are potentially where new ideas and possibilities for change emerge.

The final duty concerns the act of writing. Foucault (1977) suggests that to write is to 'show oneself, make oneself seen, make one's face appear before the other' (243) and, drawing on Seneca and Epictetus, views writing as a form of meditation which enables one to engage in 'work of thought', extended through the process of putting down thoughts, obtaining reactions from others and thinking and writing further. Writing could also be the main mechanism of provocation, whereby the academic, acting as the Socratic gadfly (or as Gogol's, 1985, 'inky thug'), could arouse, persuade and reproach its readers to see something other than their own view of the world. Len Barton (2008a) underlines the importance of being contentious in writing, 'because it assumes there will be a necessity of struggling over ideas, arguments and interpretations ... constantly re-examining and re-thinking through these issues.' These forms of writing are worlds apart from the impact factor driven approach to 
publication and the criteria for their assessment, including such elements as 'clarity' and 'coherence' in which the thinking is assumed to be complete before the article is written. Perhaps, as well as going along with these imperatives, academics need to find new outlets for writing - for example monographs or journals with an experimental purpose, many examples of which exist in the arts, and spaces in which this is encouraged, such as Open Space (www.openspaceworld.org/) and the Laboratory of Educational Theory at the Stirling Institute of Education (www.ioe.stir.ac.uk/research/LaboratoryforEducationalTheory.php).

The academic's function, in undertaking each of these duties, is 'to complicate rather than explicate' (Taylor 1995, 6), allowing them to 'approach' (Biesta 2008), rather than understand, disability, inclusive education and indeed human subjectivity. It also implies replacing understanding, which always involves tracing the partial and flawed knowledge from above, with what Taylor and Saarinen (1994) call 'interstanding', that which lies between:

When depth gives way to surface, under-standing becomes inter-standing. To comprehend is no longer to grasp what lies beneath but to glimpse what lies between ... Understanding is no longer possible because nothing stands under ... Interstanding has become unavoidable because everything stands between (Taylor and Saarinen 1994, 2-3).

The task of obtaining knowledge, or interstanding, about disability, according to Len Barton (2008a), invoves 'challenging and removing ignorance and narrow restrictive regulatory conceptions and understandings.' Interstanding about disability is logically 
achieved through, and by, disabled people and Carol Thomas (1999) advocates a narrative identity approach, in which individuals' storied self identities are set within the context of public narratives of disability, for example in the media, an approach that has parallels with 'story telling' within critical race theory (Gillborn 2008). Interstanding about inclusive education and how this might be achieved is also necessarily sought from those most closely involved with it - disabled children and their families - with insights not into techniques or 'what works' but into what makes a material difference to them and how.

The legacy of the sociology of disability, initiated by Len Barton together with other academics, both disabled and able bodied, is powerful, but is one which has not been allowed to fulfil its potential. This has partly been caused by some of the tensions and struggles within the field which has led to a series of troubling erasures, of the body within the debate on the social model of disability and of the Other in educational policies and practices. I have argued, however, that academics within the sociology of disability have minimised their own presence and consequently limited their effects. The potential of sociology of disability could be realised through a renewal of political commitment by academics and by undertaking duties which exercise responsibility to the Other. Such an engagement could provide academics with a much needed revival of their professional selves in which concerns about accountability and audit could be displaced by a desire for civic duty and for dismantling disabling and exclusionary pressures within education and society. The struggle for inclusive education would thus become one to which academics can make a significant and positive contribution by refusing to reduce it to 'quick slick 
responses' (Barton 2008b, 28) and helping instead to articulate the complex and difficult demands associated with becoming inclusive. 


\section{References}

Allan, J. 2008. Rethinking inclusion: The philosophers of difference in practice.

Dordrecht: Springer.

Allan, J., Moran, N., Duffy, C. and Loening, G. (2010) Knowledge exchange with Sistema Scotland. Journal of Education Policy 25, no 3: 335-347

Allan, J. and Slee, R. 2008. Doing inclusive education research. Rotterdam: Sense.

Ballard, K. 2003. Teaching, identity and trust. In Inclusion, participation and democracy: what is the purpose? ed. J. Allan. Dordrecht: Kluwer.

Barnes, C. and Mercer, G. 2002. Disability (Key concepts). Oxford: Blackwell Publishers.

Barnes, C., Mercer, G. and Shakespeare, T. 1999. Exploring disability: A sociological introduction. Cambridge: Polity Press.

Barton, L. 1988. The politics of special educational needs. Lewes: Falmer Press.

Barton, L. 1997. Inclusive education: romantic, subversive or realistic? International Journal of Inclusive Education 1, no. 3: 231-242.

Barton, L. 2001. Disability, struggle and the politics of hope. In Disability, politics and the struggle for change, ed. L. Barton. London: David Fulton Publishers.

Barton, L. 2005. Special educational needs: A new look. Unpublished discussion paper.

Barton, L. 2008a Routledge interview with Professor Len Barton. Interview 5. Retrieved from: http://www.educationarena.com/expertInterviews/interview5.asp\#link2 on 26 February, 2010.

Barton, L. 2008b. Inclusive education, teachers and the politics of possibility. Paper presented at the Inclusion Festival, University of Utrecht, Holland, 21 January. 
Barton, L. and Clough, P. 1995. Conclusion: Many urgent voices. In Making difficulties: Research and the construction of SEN, eds. P. Clough and L. Barton. London: Paul Chapman.

Barton, L. and Tomlinson, S. 1984. Special education and social interests. London: Harper Row.

Beckett, S. 1992. Nowhow on. London: Calder.

Biesta, G. 2008. Pedagogy with empty hands: Levinas, education and the question of being human. In Levinas and education: At the intersection of faith and reason, ed. D. Egéa-Kuehne. London/New York: Routledge.

Booth, T. 2003. Views from the insititution: overcoming barriers to inclusive education? In Developing inclusive education, eds. T. Booth, K. Nes and M. Strømstad. London: RoutledgeFalmer.

Booth, T. and Ainscow, M. 1998. From them to us: setting up the study. In From them to us: An international study of inclusion in education, eds. T. Booth and M. Ainscow. London: Routledge.

Bourdieu, P. 1998. Practical reason. Cambridge, Polity.

Brantlinger, E. 2006a. The big glossies: how textbooks structure (special) education. In Who benefits from special education? Remediating (fixing) other people's children, ed. E. Brantlinger. Mahwah, New Jersey/London: Lawrence Erlbaum Associates.

Butler, J. 2004. Precarious lives. London: Verso.

Cohen, T. 2001. Jacques Derrida and the humanities: A critical reader. Cambridge: Cambridge University Press. 
Corker, M. 1999. New disability discourse, the principle of optimisation and social change. In Disability discourse, eds. M. Corker and M. French. Buckingham: Open University Press.

Critchley, J. 1999. The ethics of deconstruction. Edinburgh: Edinburgh University Press.

Critchley, J. 2007. Infinitely demanding: Ethics of commitment, politics of resistance. London/New York: Verso.

Croll, P. and Moses, D. 2000. Ideologies and utopias: education professionals' views of inclusion. European Journal of Special Needs Education, 15, no. 1: 1-12.

Crow, L. 1992. Renewing the social model of disability. Coalition, July, 5-9.

Davis, L. 2002. Bending over backwards: Disability, dismodernism and other difficult positions. New York: New York University Press.

Derrida, J. 1990. Force of law: the mystical foundation of authority, trans. M.

Quaintance. Cardozo Law Review 11: 919-1070.

Derrida, J. 1992. The other heading: reflections on today's Europe, Trans P. Brault \& M. Naas. Bloomington and Idianapolis: Indiana University Press.

Derrida, J. 1993. Aporias. Stanford: Stanford University Press.

Dyson, A. 2001. Special needs in the twenty-first century: Where we've been and where we're going. British Journal of Special Education 28, no. 1: 24-29.

Dyson A., Howes, A. \& Roberts, B. (2002) A systematic review of the effectiveness of school-level actions for promoting participation by all students (EPPI-Centre Review, version 1.1). In Research Evidence in Education Library. London: EPPI-Centre, Social Science Research Unit, Institute of Education. 
Erevelles, N. 2006. Deconstructing difference: Doing disability studies in multicultural educational contexts. In Vital questions facing disability studies in education, eds. S. Danforth \& S. Gabel. New York: Peter Lang.

Evans, M. 2004. Killing thinking: the death of the universities. London/New York, Continuum.

Flvyberg, B. 2001. Making social science matter: Why social inquiry fails and how it can succeed again. Cambridge, MA: Cambridge University Press.

Foucault, M. 1977. A preface to transgression. In Language, countermemory, practice: Selected essays and interviews by Michel Foucault, ed. D. Bouchard. Oxford: Basil Blackwell.

French, S. 1993. Disability, impairment or something in between. In Disabling barriers, enabling environments, eds. J. Swain, S. French, C. Barnes and C. Thomas. London: Sage.

French, S. 1994. ed. On equal terms: Working with disabled people. Oxford: Butterworth-Heinemann

Furedi, F. 2004. Where have all the intellectuals gone? London: Continuum.

Gamarnikow, E. and Green, A. 2009. Social capitalism for linking professionalism and social justice in education. In Social capital, professionalism and diversity, eds. J. Allan, J. Ozga and G. Smyth. Rotterdam: Sense.

Garrison, J. 2008. Ethical obligation in caring for the other. In Levinas and education: At the intersection of faith and reason, ed. D. Egéa-Kuehne. London/New York: Routledge.

Gates, H. 1992.Statistical stigmata. In Deconstruction and the possibility of justice, eds. D. Cornell, M. Rosenfield and D. Carlson. London: Routledge. 
Gewirtz, S. and Cribb, A. 2006. What to do about values in social research: The case for ethical reflexivity in the sociology of education. British Journal of Sociology of Education 27, no. 2: 141-155.

Gewirtz, S. and Cribb, A. 2008. Differing to agree: A reply to Hammersley and Abraham. British Journal of Sociology of Education 29, no. 5: 559-562.

Gillborn, D. (2008) Racism and education: Co-incidence or conspiracy? Abingdon/New York: Routledge.

Gloucestershire Special Schools Protection League. 2005. The tide is turning on inclusion. Retrieved 3 March, 2005, from: http://www.gsspl.org.uk/

Gogol, N (1985) The government inspector. Adapted by Adrian Mitchell. London: Heinmann.

Hammersley, M. 2008. Reflexivity for what? A resonse to Gewirtz and Cribb on the role of values in the sociology of education. British Journal of Sociology of Education 29, no. 5: 649-558.

Hanko, G. 2005. Towards an inclusive school culture: the 'affective curriculum'. In Curriculum and pedagogy in inclusive education: Values into practice, eds. M. Nind, J. Rix, K. Sheehy and K. Simmons. London/New York: RoutledgeFalmer/The Open University.

Hughes, B. 2009. Wounded/monstrous/abject: a critique of the disabled body in the sociological imaginary. Disability and Society 24, no. 4: 399-410.

Kraut, R. 1992. Cambridge companion to Plato. Cambridge: Cambridge University Press.

Levinas, I. 1969. Totality and infinity. Pittsburgh: Duquesne University Press.

Levinas, I. 1996. Basic philosophical writings, eds. A. Perperzak, S. Critchley and R. Bernasconi. Bloomingon: Indiana University Press. 
Levinas, I. 1999. Alterity and transcendence. Columbia University Press: New York.

Macbeath, J., Galton, M., Steward, S., Macbeath, A. and Page, C. 2006. The costs of inclusion. Report prepared for the National Union of Teachers. Retrieved 24 September, 2006, from:

$\underline{\text { http://www.teachers.org.uk/resources/pdf/CostsofInclusion.pdf }}$

McNary, S. (2005). What successful teachers do in inclusive classrooms. London:

Sage.Mittler, P. 2000. Working towards inclusive education. London: David Fulton.

Mongon, J., Ford, D. and Whelan, M. 1982. Special education and social control:

Invisible disasters. Boston: Routledge and Kegan Paul.

Morris, J. 1991. Pride against prejudice: Transforming attitudes to disability. London: The Women's Press.

Norwich, B. 2006. Dilemmas of inclusion and the future of education. In Included or excluded? The challenge of the mainstream for some children, ed. R. Cigman. London: Routledge.

Oliver, M. 1996. Understanding disability: From theory to practice. Basingstoke: Macmillan.

Oliver, M. 1999. Final accounts and the parasite people. In Disability discourse, eds. M. Corker and S. French. Buckingham: Open University Press.

Oliver, M. and Barnes, C. 1996. Disabled people and social policy: From exclusion to inclusion. London: Longman.

Paterson, L. 2003. The survival of the democratic intellect: academic values in Scotland and England. Higher Education Quarterly 57, no. 1: 67-93.

Paterson, K. and Hughes, B. 1999. Disability studies and phenomenology: the carnal politics of everyday life. Disability and Society 14, no. 5: 597-611. 
Paterson, K. and Hughes, B. 2000. Disabled bodies. In The body, culture and society: An introduction, eds. P. Hancock, B. Hughes, E. Jagger, K. Patterson, R. Russell, E. Tulle-Winton and M. Tylor Buckingham: Open University Press. Rancière, J. 2008. Jacques Rancière and indisciplinarity. An interview. Art and Research 2, no. 1: 1-10.

Said, E. 1994. Representations of the intellectual. London: Vintage.

Shakespeare, T. 2005. For whom the school bell tolls. BBC - Ouch! 11 July http://www.bbc.co.uk/ouch/columnists/tom/270605_index.shtml Retrieved on 11 July 2007.

Shakespeare, T. 2006. Disability rights and wrongs. London: Routledge.

Shakespeare, T. and Watson, N. 1997. Defending the social model. Disability and Society 12, no. 2: 293-300.

Shildrick, M. 2002. Embodying the monster: Encounters with the vulnerable self. London: Sage.

Skrtic, T. 1995. Disability and democracy: Reconstructing [special] education for postmodernity. New York: Teachers College Press.

Slee, R. 1993. The politics of integration: new sites for old practices? Disability, Handicap and Society 8, no. 4: 351-360.

Slee, R. 2001. Inclusion in practice: does practice make perfect? Educational Review 53, no. 2: 113-123.

Slee, R. 2003. Teacher education, government and inclusive schooling: the politics of the Faustian waltz. In Inclusion, participation and democracy: what is the purpose? ed. J. Allan. Dordrecht: Kluwer.

Slee, R. and Allan, J. 2001. Excluding the included: a reconsideration of inclusive education. International Journal of Sociology of Education 11, no. 2: 173-191. 
Smyth, J. 2000. Reclaiming social capital through critical teaching. Elementary School Journal 110, no. 5: 491-511.

Spurgeon, N. 2006. Diversity and choice for children with complex learning needs. In Included or excluded? The challenge of the mainstream for some children, ed. R. Cigman. London: Routledge.

Strathern, M. 1997. Improving ratings: audit in the British university system. European Review 5, no. 3: 305-321.

Strathern, M. 2000. Audit cultures: anthropological studies in accountability, ethics and the academy. London: Routledge.

Swain, J. and French, S. 2008. Disability on equal terms. London: Sage.

Taylor, M. 1995. Rhizomic folds of interstanding. Tekhnema 2: Technics and Finitude, Spring. Retrieved 27 June, 2003, from: http://tekhnema.free.fr/2Taylor.htm

Taylor, M. and Saarinen, E. 1994. Imagologies: Media philosophy. London: Routledge.

Thomas, C. 1999. Female forms: Experiencing and understanding disability. Buckingham: Open University Press.

Thomas, C. 2007. Sociologies of disability and illness: Contested ideas in disability studies and medical sociology. London: Palgrave Macmillan.

Thomas, G. 2008. Theory and the construction of pathology, Paper presented at the American Educational Research Association, New York, 24-28 March.

Thomas, G. and Vaughan, M. 2004. Inclusive education: readings and reflections. Maidenhead: Open University Press.

Tomlinson, S. 1981. Educational subnormality: A study in decision-making. London: Routledge \& Kegan Paul. 
Tomlinson, S. 1982. A sociology of special education. London: Routledge \& Kegan Paul.

Torrance, H. 2008. Building confidence in qualitative research: engaging the demands of policy. Qualitative Inquiry 14, no. 4: 507-527.

Walford, G., Halpin, D. and Troyna, B. 1994. Political commitment in the study of the City Technology College, Kinghurst. In Researching education policy: ethical and methodological issues, eds. D. Halpin and B. Troyna. London: Falmer Press.

Warnock, M. 2005. Special educational needs: a new look. Impact No 11. London: The Philosophy Society of Great Britain.

Westwood, P (2002). Commonsense methods for children with special educational needs. London: FalmerRoutledge.

Wing, L. 2006. Children with autistic spectrum disorders. In Included or excluded? The challenge of the mainstream for some children, ed. R. Cigman. London: Routledge. 